https://dx.doi.org/10.4314/ijs.v23i1.4

Ife Journal of Science vol. 23, no. 1 (2021)

\title{
PHYTOAVAILABLILITY AND FRACTIONATION OF CADMIUM AND LEAD IN VEGETABLE FARM SOILS IN ILORIN, NORTH-CENTRAL, NIGERIA
}

\author{
Ben-Uwabor, P. O. ${ }^{1}$, Olawepo, G. K. ${ }^{2}$, Ogunkunle, C. O. ${ }^{3}$ Fatoba, O. P. ${ }^{4}$ \\ ${ }^{1}$ Department of Natural and Environmental Sciences, Crown-Hill University, Eiyenkorin, Kwara State, Nigeria. \\ ${ }^{234}$ Department of Plant Biology, Faculty of Life Sciences, University of Ilorin, Ilorin, Kwara State, Nigeria. \\ *Corresponding author's e- mail: patiencebenuwabor@gmail.com \\ E-mail address of other authors: ${ }^{2}$ okg4eva@yahoo.com; ${ }^{3}$ seyeogunkunle@gmail.com and \\ pofatoba57@yahoo.com. \\ (Revision received: $4^{\text {th }}$ August, 2020; Accepted: $12^{\text {th }}$ January, 2021)
}

ABSTRACT

\begin{abstract}
Heavy metal dynamics, bioavailability and fractionation are of great importance to measure soil toxicity, remediation strategies and availability in soil. However, reports showed that not much has been done to evaluate these parameters in vegetable farm soils in Ilorin metropolis. These parameters aid in assessing risk potential and extent of heavy metal viability in soil. Therefore, soils were collected from major vegetable farms in Ilorin metropolis, sorted, air-dried, ground, and pretreated for further analysis. Thus, this study investigated the bioavailable $\mathrm{Cd}$ and $\mathrm{Pb}$ and their fractionation in vegetable farm soils in Ilorin metropolis. These experiments were conducted by single extraction procedure, sequential extraction and Atomic Absorption Spectrophotometry, alongside analysis of some key soil properties. The results showed that the soil $\mathrm{pH}$ ranged from $6.62 \pm 0.04$ to $7.18 \pm 0.03$, organic matter $2.05 \pm 00 \%$ to $3.50 \pm 005 \%$ and cation exchangeable capacity $3.68 \pm 0.02 \mathrm{cmolc} / \mathrm{kg}$ to $8.63 \pm 0.03 \mathrm{cmolc} / \mathrm{kg}$. The target heavy metals in the sampling areas were potentially bioavailable with phytoavailable concentration ranges of $0.00 \pm 0.00 \mathrm{mg} / \mathrm{kg}$ to $0.67 \pm 0.14 \mathrm{mg} / \mathrm{kg}$ for Cd and $0.33 \pm 0.03 \mathrm{mg} / \mathrm{kg}$ to $6.25 \pm 0.25 \mathrm{mg} / \mathrm{kg}$ for Pb. The target heavy metals showed a high viability of the soluble and exchangeable form in most soils and in both seasons which would greatly contribute to their availability to plant uptake and soil toxicity. There is also a threat of oxidization of the potentially available $\mathrm{Cd}$ and $\mathrm{Pb}$ in other forms due to $\mathrm{pH}$ ranges of most of the studied soils. Therefore, vegetable farm soils in Ilorin metropolis are polluted with $\mathrm{Cd}$ and $\mathrm{Pb}$ and may have high risk of causing human health problems when vegetables grown on the soils are consumed; which calls for remediation of most of the soils.
\end{abstract}

Keywords: Phytoavailability, Fractionation, Pollution, Heavy metal, Sequential extraction, Vegetable farm soils.

\section{INTRODUCTION}

Heavy metals abound naturally in soil environment, as a result of processes of weathering of parent materials at levels that are regarded as trace and rarely toxic substance, and also from human anthropogenic activities (Herawati et al, 2010). Of the heavy metals that abound, cadmium $(\mathrm{Cd})$ and lead $(\mathrm{Pb})$ are common and widely studied contaminants because of their spectrum of use in production of lead-acid batteries, lead-based paints, automobiles, oil refineries, and antiknock in petrol (Ying et al., 2013). In terms of environmental concentration, $\mathrm{Pb}$ is the heavy metal closest to the level in which toxic signs manifest than any other substance (Iwegbue et al., 2013).

Heavy metal distribution, dynamics and transport in soil depend significantly on their chemical forms (Debnárová and Doleța, 2010). Once in the soil, heavy metals are adsorbed by initial fast reactions (minutes, hours), followed by slow adsorption reactions (days, years) and are, therefore, redistributed into different chemical forms with varying bioavailability, mobility and toxicity (Deng et al., 2012).

Reports had shown that not all the heavy metals in the soil are readily available to plant but may become available under some environmental influences or changes such as $\mathrm{pH}$, redox potential, cation exchange capacity, organic matter content and moisture content of the soil (Yadawe, 2011). The fraction of a total heavy metal content that is available for plant uptake in the soil depends strongly on the chemical form in which the metals are present (Lokeshwari and Chandrappa, 2012). Therefore, it is important to know the different forms of heavy metals in soil which will help in assessing the extent of toxicity or level of contaminations and remediation strategy of the heavy metal (Kabata-Pendias, 2004). The largest 
form of the metals is bound to the soil solid form which is the form that controls the metal ion activity in the soil solution (Menzies et al., 2007).

It has been established that the total concentrations of metals in soil do not provide information about metal phytoavailability. The chemical forms in which metals are present in soil determines the phytoavailability, mobility, and reactivity (Yadawe, 2011). The accurate estimation of heavy metal phytoavailability and fractionation in soils had been reported to be important risk assessment, remediation strategy and a measure its viability to plant (KabataPendias, 2004). Heavy metal fractionation are the different chemical and physical forms of heavy metals in soil, which can be free ion or complexed to a ligand (Davidson et al., 2006). It can be in the gaseous form, and distributed amongst solid phases within the soil (Manceau et al., 2002).

There are five main chemical forms of heavy metals, and these are: exchangeable heavy metals which are the phytobioavailable or soluble fraction (FI), heavy metals bound to carbonate (F2), heavy metals bound to oxide (F3), heavy metals bound to organics fraction (F4) and residual heavy metals (F5) (Oluwatosin et al., 2010). Heavy metals in soil are redistributed to different chemical forms with varying bioavailability, mobility and toxicity (Levy, 1992). Therefore, for a comprehensive description and understanding of phytoavailability of heavy metals in soils, there would be need to address all the various forms of a metal in soils (Haung, 2005).

Hence, assessment of phytoavailability and fractionation of heavy metals in agricultural soils becomes very essential in order to avoid pollution via food chain by heavy metals in soils (Haung et al., 2005).

Zerbe et al. (1999) reported that $\mathrm{Cd}$ and $\mathrm{Pb}$ fractionations and their bioavailability in soil in the fractions of carbon-bound (F2) and oxides-bound (F3) contribute greatly to their availability to plant uptake (Forstner, 1993).

Therefore, vegetables grown on soils with elevated phytoavailable $\mathrm{Cd}$ and $\mathrm{Pb}$ stand the risks of being contaminated, and consumers of such vegetable stand the risk of picking up such contaminants, which leads to health deterioration.

\section{MATERIALS AND METHODS Soil Sample Collection}

Thirteen (13) selected top soils $(0-15 \mathrm{~cm})$ from the major vegetable farms in Ilorin metropolis were used. The soil of the University of Ilorin Botanical Garden was used as Control because literature has certified the concentrations of heavy metals of University of Ilorin Botanical Garden soil as suitable for Control with concentrations far below the WHO (2006) standard for agricultural soils.

Soils from sampling sites differ in physical and chemical properties and in the degrees of heavy metal contamination (Rayment and Higginson, 1992). Their textures ranged from sandy loam to clay with different anthropogenic activities around the sampling areas (Table 1).

Otte, Budo Egba, Mubo and Oyun sampling sites are located along the road. Sites of Coca Cola and Ola olu areas are located close to industrial layout, mechanic workshop and the road. Sites of Ojagboro and Isale Aluko are near major dumpsites while sites of Budo Abio and Odoore had low anthropogenic activities.

Sample collection was done both in the dry season (November, 2015 to February, 2016) and in the rainy season (August, 2016 to October, 2016) for this study.

\section{Preparation and Characterization}

Each soil sample was separately passed through a $10 \mathrm{~mm}$ sieve to remove large stones and grass debris, air-dried, ground, and passed through a $2 \mathrm{~mm}$ sieve for further laboratory analysis (AOAC, 2000).

The $\mathrm{pH}$ of each soil sample was measured in deionized water $(1: 1, \mathrm{w} / \mathrm{v})$ with a glass electrode using the method of Obrador et al. (2007). The organic matter $(\mathrm{OM})$ content was determined via the Walkley-Black wet oxidation method of Reddy (2002). Cation exchange capacity (CEC) was determined using the ammonium acetate method ( $\mathrm{pH}$ 7.0) according to the method of Rhoades et al. (1982). 
Table 1: Description of the Sampling Sites in Ilorin, Nigeria and their GPS Coordinates

\begin{tabular}{llllllll}
\hline S/NO & Sites & LOC & AA & ST & $\begin{array}{l}\text { Latitude } \\
(\mathrm{N})\end{array}$ & $\begin{array}{l}\text { Longitude } \\
(\mathrm{E})\end{array}$ & Altitude (Meters) \\
\hline 1 & Otte & ATR & HVE:MAA & L & $8^{0} 31^{1}$ & $4^{0} 39^{1}$ & 347.0 \\
2 & Budo Egba & ATR & HVE:LAA & LS & $8^{0} 32^{1}$ & $4^{0} 39^{1}$ & 346.6 \\
3 & Budo Abio & BTN & LAA & L & $8^{0} 30^{1}$ & $4^{0} 53^{1}$ & 365.0 \\
4 & Mubo & WTN:ATR & DW:HVE:HDS & L & $8^{0} 50^{1}$ & $4^{0} 70^{1}$ & 270.4 \\
5 & Oyun & ATR & VHE:HDW & L & $8^{0} 53^{1}$ & $4^{0} 60^{1}$ & 284.5 \\
6 & Ojagboro & BTN & HD:HDW & L & $8^{0} 15^{1}$ & $4^{0} 57^{1}$ & 262.2 \\
7 & Olaolu & ATH: IA & HVE: HIW & LS & $8^{0} 47^{1}$ & $4^{0} 57^{1}$ & 282.7 \\
8 & Eroomo & WTN & MAA & LS & $8^{0} 45^{1}$ & $4^{0} 58^{1}$ & 327.1 \\
9 & Okeodo & ATR & HVE: MDS & LS & $8^{0} 47^{1}$ & $4^{0} 64^{1}$ & 332.8 \\
10 & Cocacola & IA: ATR & HIW: HVE: HDS & LS & $8^{0} 47^{1}$ & $4^{0} 56^{1}$ & 265.5 \\
11 & Isale Aluko & WTN & HDS:HDW:HDS & L & $8^{0} 49^{1}$ & $4^{0} 54^{1}$ & 302.9 \\
12 & Odoore & BTN & LAA & L & $8^{0} 43^{1}$ & $4^{0} 50^{1}$ & 354.1 \\
13 & Botanical & OTR & LAA & L & $8^{0} 47^{1}$ & $4^{0} 66^{1}$ & 290.9 \\
\hline
\end{tabular}

Abbreviations: LGA - Local Government Area, N-North of the Equator, E-East of the Greenwich Meridian, CS-Control Site, LOC- Location, ATR-Along the Road, IA- Industrial Area, HIW- Heavy Industrial Waste, WTN- Within The Neighborhood, BTN- Behind The Neighborhood, OTR-Off The Road, LVE- Low Vehicular Emission, MVE-Moderate Vehicular Emission, HVE- Heavy Vehicular Emission, AA-Anthropogenic Activities, LAA- Low Anthropogenic Activities, MAA- Moderate Anthropogenic Activities, MDS-Moderate Dump Site, HDS-Heavy Dump Site, HDW- Heavy Domestic Waste, ST-Soil Texture, L- Loam, LS- Loam Sandy.

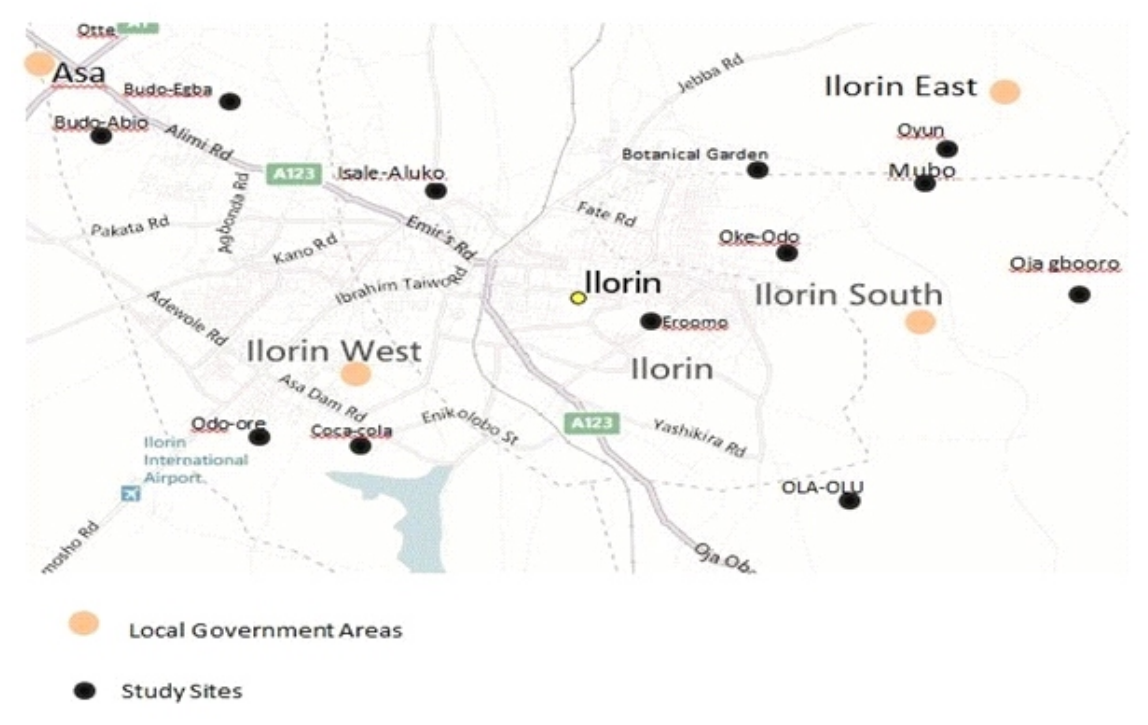

Figure 1: Map of Ilorin Metropolis, Kwara State, Nigeria, Showing the Sampling Sites

Single Extraction Procedure for Phytoavailability of Heavy Metals.

Phytoavailable heavy metal analysis of the soil samples were done using single extraction procedure of Tessier et al. (1979) and Song et al. (2008). One (1) g each of the air-dried pre-sieved composite top soil sample was weighed into a 100 $\mathrm{ml}$ volumetric flask. It was extracted at room temperature with $8 \mathrm{ml}$ of magnesium chloride solution $\left(0.5 \mathrm{M} \mathrm{MgCl}_{2}\right)$ by continuous agitation at $\mathrm{pH} 7$ for 20 mins. Extracted solution and the blank $\left(\mathrm{MgCl}_{2}\right)$ were filtered using Whatman No 42 filter paper and $<0.45 \mu \mathrm{m}$ Millipore filter paper. Each filtrate was transferred into a $25 \mathrm{ml}$ volumetric bottle and made up to the mark with distilled water. Phytoavailable contents of $\mathrm{Cd}$ and $\mathrm{Pb}$ in the soil filtrates were analyzed using Perkin Elmer 200 Analyst Spectrophotometer (AAS).

\section{Tessier's Sequential Extraction for $\mathrm{Cd}$ and $\mathrm{Pb}$ Fractionation}

The different forms of $\mathrm{Cd}$ and $\mathrm{Pb}$ in soils were determined using the method of Tessier et al. (1979) and Joksic (2005). Exchangeable heavy 
metal fractions were extracted in $20 \mathrm{ml}$ of $\mathrm{NH}_{4} \mathrm{NO}_{3}$ solution. The heavy metals bound to carbonate fraction were extracted in $16 \mathrm{ml}$ of $1 \mathrm{M}$ sodium acetate/acetic acid buffer at $\mathrm{pH} 5$ for 5 hours at room temperature. Heavy metals bound to oxide fraction were extracted in $13.9 \mathrm{~g}$ of hydroxyl amine hydrochloride $\left(\mathrm{NH}_{2} \mathrm{OH} \cdot \mathrm{HCl}\right)$ dissolved in $500 \mathrm{ml}$ of distilled water $(0.4 \mathrm{M}$ $\left.\mathrm{NH}_{2} \mathrm{OH} \cdot \mathrm{HCl}\right)$. Heavy metals bound to organic fraction were extracted in $3 \mathrm{ml}$ of $0.02 \mathrm{M} \mathrm{HNO}_{3}$ and $5 \mathrm{ml}$ of $30 \%(\mathrm{v} / \mathrm{v})$ hydrogen peroxide while the residual heavy metals fraction were extracted in $5 \mathrm{ml}$ conc. $\mathrm{HNO}_{3}\left(\mathrm{HNO}_{3}, 70 \% \mathrm{w} / \mathrm{w}\right), 10 \mathrm{ml}$ of hydrofluoric acid (HF, 40\% w/w) and $10 \mathrm{ml}$ of perchloric acid $\left(\mathrm{HClO}_{4}, 60 \% \mathrm{w} / \mathrm{w}\right)$ in Teflon beakers.

The forms of heavy metals in each extract were determined using PerkinElmer 200 Analyst Spectrophotometer (AAS). The procedure was validated and the instrument calibrated. Blanks were prepared for correction of background and other sources of error. The results of the sequential extraction were checked by summing up the different concentrations of fractions for each element and compared with the results obtained from the total heavy metals in the soils

\section{Statistical Analysis}

The means and standard deviations (SD) were calculated using Excel (Microsoft Inc.) software packages. One-way analysis of variance (ANOVA) was carried out with SPSS16.0. The statistical difference $(\phi<0.05)$ observed between samples and multiple comparisons were made by Duncan multiple range test.

\section{RESULTS AND DISCUSSION}

Tables 2 and 3 showed the results of the selected soil properties and the phytoavailable target heavy metal concentrations (extractable fractions) in both dry and rainy seasons.

The results showed that the soils used for this study varied widely in their properties, there was significant difference in the mean content of physicochemical properties $(\mathrm{pH}$, organic matter content $(\mathrm{OM})$ and cation exchangeable capacity (CEC)) and the phytoavailable heavy metals in soils of the study sites in both seasons at $\mathrm{p} \leqslant 0.05$.
The soil $\mathrm{pH}$ of study sites ranged from slightly acidic to slightly alkaline with the range of $6.62 \pm 0.04$ and $7.18 \pm 0.03$ during the dry season while the range was $6.59 \pm 0.08$ and $6.97 \pm 0.19$ during the rainy season.

All soils were characterized by low and medium organic carbon contents ranging from $2.09 \pm 0.01 \%$ to $3.50 \pm 0.05 \%$ during the dry season while in the rainy season it ranged from $2.24 \pm 0.11 \%$ to $3.01 \pm 0.20 \%$. The cation exchangeable capacity (CEC) in the dry season ranged from $3.68 \pm 0.02 \mathrm{cmol}_{\mathrm{C}} \mathrm{kg}^{-1}$ to $8.63 \pm 0.03$ $\mathrm{cmol}_{\mathrm{C}} \mathrm{kg}^{-1}$ while in the rainy season it ranged from $4.61 \pm 0.71 \mathrm{cmol}_{\mathrm{C}} \mathrm{kg}^{-1}$ to $6.09 \pm 1.11 \mathrm{cmol}_{\mathrm{C}} \mathrm{kg}^{-1}$. Soil of Mubo had the highest values of $\mathrm{pH}$ and organic matter in the dry season, which was higher than the value obtained in the rainy season.

All the soils from the study sites had $\mathrm{pH}$ and organic carbon range between the WHO/EU (2006) permissible limit for agriculture soils. The soil $\mathrm{pH}(5.5-7.5)$ and organic matter content (1\%$6 \%$ in both seasons had higher values in the dry season than in the rainy season.

Soil of Odoore had the highest CEC than all the other soils in the dry season. This indicated more clay and organic matter in the soil, hence, greater water holding capacity and more fertility than soils of the other sites. The phytoavailable target heavy metals of vegetable soils in Ilorin metropolis in the dry season showed that there was significant difference between the Control soil and all the other soils at $\mathrm{P}<0.05$. The study indicated that the phytoavailable heavy metals in the soils varied significantly among sites and between seasons as shown by earlier study of Atayese et al. (2009).

It was also revealed in this study that $\mathrm{Cd}$ was more phytoavailable in the dry season than in the rainy season. This is consistent with the findings of Ashraf et al. (2012), and it could be attributed to the $\mathrm{pH}$ range and the cation exchange capacity of the soil supporting $\mathrm{Cd}$ complexation in the dry season than in the rainy season. The lowest phytoavailable Cd was obtained for the Control soil, which could be due to low pollution from agricultural practices or anthropogenic activities.

It was shown in this study that mostly all soils 
showed elevated levels of phytoavailable cadmium and lead in the dry season except for soil of the Eroomo, Odoore and the Control site while lead was more phyoavailable in the rainy season than cadmium. The reason could be due to seasonal variation which could have been supported by the soil physicochemical properties like the $\mathrm{pH}$, soil organic matter and the cation exchange capacity of the soil which corroborates the submission of Yadawe (2011). Mostly all the soils of the study sites stand the risk of pollution by $\mathrm{Cd}$ and $\mathrm{Pb}$ most especially in the dry season with most values above the WHO (2006) permissible value of phytoavailable $\mathrm{Cd}$ of $0.3 \mathrm{mg} / \mathrm{kg}$.
Therefore, the result showed that extractable portion or the phytoavailable form of $\mathrm{Cd}$ $(0.11 \pm 0.0 \mathrm{mg} / \mathrm{kg}$ to $0.67 \pm 0.14 \mathrm{mg} / \mathrm{kg})$ in most of the sites were greater than the permissible limit of $\mathrm{Cd}$ while the soluble portion of lead $(\mathrm{Pb})$ in soils in both seasons were between $0.33 \pm 0.03 \mathrm{mg} / \mathrm{kg}$ and $6.25 \pm 0.25 \mathrm{mg} / \mathrm{kg}$. The result indicated $\mathrm{Cd}$ and $\mathrm{Pb}$ pollution in the soils of these sites which is an indication that most of the soils need to be remediated for planting.

The result also indicated strong relationship between the phytoavailable heavy metal concentrations and soil properties (Tables 2 and 3 ) which agrees with findings of Zurera et al. (1989).

Table 2: Physicochemical Properties, Phytoavailable $\mathrm{Cd}$ and $\mathrm{Pb}(\mathrm{mg} / \mathrm{kg})$ in Vegetable Farm Soils at some Sites in Ilorin, Nigeria during Dry Season

\begin{tabular}{lllllc}
\hline Site & $\mathrm{pH}$ & $\mathrm{OM} \%$ & $\begin{array}{l}\mathrm{CEC} \\
\mathrm{cmocl} \mathrm{kg}\end{array}$ & $\mathrm{Cd}$ & $\mathrm{Pb}$ \\
\hline Otte & $6.93 \pm 0.1^{\mathrm{c}}$ & $2.23 \pm 0.01^{\mathrm{i}}$ & $6.51 \pm 0.09^{\mathrm{bc}}$ & $0.42 \pm 0.02^{\mathrm{bcd}}$ & $0.83 \pm 0.14^{\mathrm{fg}}$ \\
Budo Egba & $6.62 \pm 0.04^{\mathrm{h}}$ & $3.07 \pm 0.02^{\mathrm{c}}$ & $5.56 \pm 0.01^{\mathrm{e}}$ & $0.50 \pm 0.00^{\mathrm{b}}$ & $1.33 \pm 0.31^{\mathrm{efg}}$ \\
Budo Abio & $6.88 \pm 0.01^{\mathrm{d}}$ & $2.47 \pm 0.05^{\mathrm{g}}$ & $5.04 \pm 0.03^{\mathrm{h}}$ & $0.33 \pm 0.02^{\mathrm{cd}}$ & $1.92 \pm 0.40^{\mathrm{ef}}$ \\
Mubo & $7.18 \pm 0.03^{\mathrm{a}}$ & $3.50 \pm 0.05^{\mathrm{a}}$ & $5.93 \pm 0.04^{\mathrm{cd}}$ & $0.50 \pm 0.03^{\mathrm{b}}$ & $1.92 \pm 0.11^{\mathrm{ef}}$ \\
Oyun & $7.05 \pm 0.04^{\mathrm{b}}$ & $3.20 \pm 0.02^{\mathrm{b}}$ & $5.43 \pm 0.02^{\mathrm{f}}$ & $0.42 \pm 0.03^{\mathrm{bcd}}$ & $2.92 \pm 0.27^{\mathrm{de}}$ \\
Ojagboro & $6.81 \pm 0.01^{\mathrm{f}}$ & $2.77 \pm 0.02^{\mathrm{e}}$ & $5.21 \pm 0.03^{\mathrm{g}}$ & $0.45 \pm 0.08^{\mathrm{bcd}}$ & $5.17 \pm 0.20^{\mathrm{ab}}$ \\
Olaolu & $6.69 \pm 0.01^{\mathrm{f}}$ & $2.46 \pm 0.03^{\mathrm{g}}$ & $4.05 \pm 0.01^{\mathrm{j}}$ & $0.25 \pm 0.05^{\mathrm{d}}$ & $4.37 \pm 0.40^{\mathrm{b}}$ \\
Eroomo & $6.63 \pm 0.04^{\mathrm{hg}}$ & $2.53 \pm 0.02^{\mathrm{f}}$ & $5.89 \pm 0.01^{\mathrm{d}}$ & $0.17 \pm 0.03^{\mathrm{de}}$ & $3.17 \pm 0.11^{\mathrm{cde}}$ \\
Okeodo & $6.85 \pm 0.01^{\mathrm{e}}$ & $2 . .97 \pm 0.04^{\mathrm{d}}$ & $6.55 \pm 0.01^{\mathrm{b}}$ & $0.25 \pm 0.00^{\mathrm{d}}$ & $3.75 \pm 0.78^{\mathrm{cd}}$ \\
Coca cola & $7.08 \pm 0.04^{\mathrm{b}}$ & $2.05 \pm 0.02^{\mathrm{j}}$ & $5.84 \pm 0.06^{\mathrm{d}}$ & $0.67 \pm 0.14^{\mathrm{a}}$ & $5.83 \pm 0.46^{\mathrm{a}}$ \\
IsaleAluko & $6.94 \pm 0.01^{\mathrm{c}}$ & $2.36 \pm 0.02^{\mathrm{h}}$ & $3.68 \pm 0.02^{\mathrm{k}}$ & $0.53 \pm 0.04^{\mathrm{b}}$ & $1.50 \pm 0.18^{\mathrm{fg}}$ \\
Odoore & $6.68 \pm 0.01^{\mathrm{f}}$ & $2.09 \pm 0.01^{\mathrm{j}}$ & $8.63 \pm 0.03^{\mathrm{a}}$ & $0.14 \pm 0.03^{\mathrm{a}}$ & $0.92 \pm 0.16^{\mathrm{f}}$ \\
Bot.garden $(\mathrm{CS})$ & $6.67 \pm 0.01^{\mathrm{fg}}$ & $2.56 \pm 0.03^{\mathrm{f}}$ & $4.83 \pm 0.03^{\mathrm{i}}$ & $0.11 \pm 0.02^{\mathrm{e}}$ & $0.50 \pm 0.07^{\mathrm{h}}$ \\
\hline
\end{tabular}

Mean value with same alphabet along the same column are significantly the same at $\mathrm{p} \leqslant 0.05$ using Duncan Multiple Range Test, CS: Control Site, OM: Organic matter, CEC: Cation Exchangeable Capacity. WHO (2006) safe limit of Cd=0.03 $\mathrm{mg} / \mathrm{kg}$ and $\mathrm{Pb}=2.00 \mathrm{mg} / \mathrm{kg}$. 
Table 3: Physicochemical Properties, Phytoavailable $\mathrm{Cd}$ and $\mathrm{Pb}(\mathrm{mg} / \mathrm{kg})$ in Vegetable Farm Soils at some Sites in Ilorin, Nigeria during Rainy Season

\begin{tabular}{llllll}
\hline Site & Ph & OM \% & $\begin{array}{l}\text { CEC } \\
\text { cmolc kg }\end{array}$ & Cd & Pb \\
\hline Otte & $6.91 \pm 0.16^{\mathrm{ab}}$ & $3.01 \pm 0.20^{\mathrm{a}}$ & $6.01 \pm 0.80^{\mathrm{ab}}$ & $0.08 \pm 0.04^{\mathrm{a}}$ & $4.08 \pm 0.12^{\mathrm{bc}}$ \\
Budo Egba & $6.97 \pm 0.19^{\mathrm{a}}$ & $2.65 \pm 0.50^{\mathrm{bc}}$ & $5.86 \pm 0.68^{\mathrm{b}}$ & $0.08 \pm 0.02^{\mathrm{a}}$ & $4.27 \pm 0.03^{\mathrm{ab}}$ \\
Budo Abio & $6.88 \pm 0.16^{\mathrm{ab}}$ & $2.45 \pm 0.48^{\mathrm{d}}$ & $5.90 \pm 0.61^{\mathrm{b}}$ & $0.00 \pm 0.00^{\mathrm{b}}$ & $0.68 \pm 0.12^{\mathrm{e}}$ \\
Mubo & $6.77 \pm 0.23^{\mathrm{ab}}$ & $2.37 \pm 0.41^{\mathrm{de}}$ & $5.67 \pm 0.27^{\mathrm{b}}$ & $0.08 \pm 0.00^{\mathrm{a}}$ & $4.30 \pm 0.29^{\mathrm{ab}}$ \\
Oyun & $6.75 \pm 0.05^{\mathrm{ab}}$ & $2.41 \pm 0.27^{\mathrm{d}}$ & $6.09 \pm 1.11^{\mathrm{a}}$ & $0.08 \pm 0.11^{\mathrm{a}}$ & $3.97 \pm 0.63^{\mathrm{bcc}}$ \\
Ojagboro & $6.70 \pm 0.17^{\mathrm{ab}}$ & $2.37 \pm 0.16^{\mathrm{d}}$ & $5.60 \pm 1.80^{\mathrm{b}}$ & $0.08 \pm 0.03^{\mathrm{a}}$ & $2.33 \pm 0.12^{\mathrm{c}}$ \\
Olaolu & $6.71 \pm 0.13^{\mathrm{ab}}$ & $2.31 \pm 0.14^{\mathrm{d}}$ & $5.45 \pm 1.84^{\mathrm{bc}}$ & $0.08 \pm 0.03^{\mathrm{a}}$ & $3.58 \pm 0.02^{\mathrm{b}}$ \\
Eroomo & $6.59 \pm 0.08^{\mathrm{b}}$ & $2.28 \pm 0.22^{\mathrm{e}}$ & $4.61 \pm 0.71^{\mathrm{c}}$ & $0.00 \pm 0.00^{\mathrm{c}}$ & $0.65 \pm 0.36^{\mathrm{j}}$ \\
Okeodo & $6.60 \pm 0.06^{\mathrm{b}}$ & $2.24 \pm 0.11^{\mathrm{e}}$ & $5.31 \pm 0.19^{\mathrm{bc}}$ & $0.08 \pm 0.11^{\mathrm{a}}$ & $2.42 \pm 0.38^{\mathrm{c}}$ \\
Coca cola & $6.72 \pm 0.28 \mathrm{a}^{\mathrm{b}}$ & $2.48 \pm 0.55^{\mathrm{cd}}$ & $5.33 \pm 0.31^{\mathrm{bc}}$ & $0.08 \pm 0.14^{\mathrm{a}}$ & $6.25 \pm 0.25^{\mathrm{a}}$ \\
IsaleAluko & $6.86 \pm 0.26^{\mathrm{ab}}$ & $2.57 \pm 0.44^{\mathrm{c}}$ & $5.16 \pm 0.58^{\mathrm{bc}}$ & $0.08 \pm 0.11^{\mathrm{a}}$ & $1.82 \pm 0.38^{\mathrm{d}}$ \\
Odoore & $6.92 \pm 0.15^{\mathrm{ab}}$ & $2.75 \pm 0.48^{\mathrm{b}}$ & $5.51 \pm 0.92^{\mathrm{b}}$ & $0.00 \pm 0.00^{\mathrm{b}}$ & $0.44 \pm 0.12^{\mathrm{ef}}$ \\
Botanical garden (CS) & $6.93 \pm 0.18^{\mathrm{ab}}$ & $2.84 \pm 0.47^{\mathrm{ab}}$ & $5.31 \pm 0.99^{\mathrm{b}}$ & $0.00 \pm 0.00^{\mathrm{b}}$ & $0.33 \pm 0.03^{\mathrm{f}}$ \\
\hline
\end{tabular}

Mean value with same alphabet along the same column are significantly the same at $\mathrm{p} \leqslant 0.05$ using Duncan Multiple Range Test, CS: Control Site, OM: Organic carbon, CEC=Cation Exchangeable Capacity. WHO (2006) safe limit of $\mathrm{Cd}=0.03$ $\mathrm{mg} / \mathrm{kg}$ and $\mathrm{Pb}=2.00 \mathrm{mg} / \mathrm{kg}$.

Tables 4-5 showed that $\mathrm{Cd}$ fractionation in soil varied significantly among sites and between seasons supporting the study of Diaz-de Alba et al. (2011). There was significant difference in the fractions of cadmium between the sites and seasons at $\mathrm{p} \leqslant 0.05$. The fraction of cadmium $(\mathrm{Cd})$ in the exchangeable (F1), bound to carbonate (F2) and residual forms (F5) were more in the soil in dry season indicating more soluble or labile $\mathrm{Cd}$ in soil in dry season, while the oxide (F3) and organic (F4) forms of $\mathrm{Cd}$ were more in the rainy season. Low amount of $\mathrm{Cd}$ bound to residual fraction compared with that in other geochemical phases indicated higher mobility of the metal in the soil. Similar result was reported in another related study (Ashraf et al., 2012). This showed that Cd would easily be released to the soil and highly toxic under favorable conditions like $\mathrm{pH}$, organic matter, cation exchangeable capacity and electrical conductivity.

Soils of Otte and Budo Egba had more of the exchangeable $\mathrm{Cd}$ than the soils from other sites. Soil of the Control soil recorded zero value for all the forms of $\mathrm{Cd}$ except the $\mathrm{Cd}$ bound to residual fraction. The $\mathrm{Cd}$ residual fraction in the Control soil could be due to geogenic origin and complexation of $\mathrm{Cd}$ with the soil sediments being released after degradation of organic matter which corroborates the study of Cabral and Lefebvre (1998). The soluble and exchangeable heavy metal form of $\mathrm{Cd}$ usually considered as most hazardous (Maiz et al., 2000), were more in the dry season than in the rainy season. This is similar to the report of Gupta et al. (2005) that got more soluble fraction of cadmium in the dry season than in the rainy season.

This could be due to the low soil $\mathrm{pH}$ and cation exchange capacity in the dry season than in the rainy season that supported $\mathrm{Cd}$ mobility and dynamic in soil which would likely render the soils more polluted by Cd. Tables 6 and 7 showed significant differences in the fractionation of $\mathrm{Pb}$ in both seasons. Lead was more bound to carbonate (F2), oxide (F3) and organics (F4) in the soil in the dry season unlike $\mathrm{Cd}$, while $\mathrm{Pb}$ in the rainy season was more in the forms of exchangeable (F1) and residual fraction. Soils of Otte, Olaolu, Okeodo and Isale Aluko recorded higher exchangeable $\mathrm{Pb}$ than soils of the other sites in the dry season. The soils of the Control site in the rainy season were more contaminated with $\mathrm{Pb}$ than in the dry season with $\mathrm{Pb}$ bound to carbonate, oxides and organics in the soils. The results suggested that $\mathrm{Cd}$ and $\mathrm{Pb}$ fractionation in the soils varies with season which can be due to difference in the physico-chemical properties of 
soils such as $\mathrm{pH}$, organic matter, cation exchangeable capacity, electrical conductivity, soil moisture, bulk density and clay matter.

The soils of some sites such as Otte, Budo Egba, Ola olu, Okeodo, Coca Cola and Isale Aluko were contaminated with both $\mathrm{Cd}$ and $\mathrm{Pb}$. This could be due to the activities around the sampling areas such as agricultural activities, proximity to the road, thereby receiving vehicular emission, exhausts from mechanic workshops, industrial discharge and solid wastes of dumpsite. The result showed that the resultant difference in the wastes were sources of heavy metals from activities from those areas which could lead to complexation of heavy metals with sediments being released after oxidation of sulphides from wastes to sulphates. The oxidized complexes are weakly bound and are readily available in soil at suitable environmental conditions (Diaz-de Alba et al.,2011). There was an indication that fractions of $\mathrm{Cd}$ and $\mathrm{Pb}$ in the soils of the sampling sites are directly related to their solubility which controls its mobility as reported by Xian (1989).

Table 4: Fractionation of $\mathrm{Cd}(\mathrm{mg} / \mathrm{kg})$ in the Vegetable Farm Soils at some Sites in Ilorin, Nigeria during Dry Season

\begin{tabular}{llllll}
\hline Sites & $\begin{array}{l}\text { Exchangeable } \\
\text { Fraction }\end{array}$ & $\begin{array}{l}\text { BTCarbon } \\
\text { Fraction }\end{array}$ & $\begin{array}{l}\text { BTOxides } \\
\text { Fraction }\end{array}$ & $\begin{array}{l}\text { BTOrganic } \\
\text { Fraction }\end{array}$ & $\begin{array}{l}\text { Residual Cd/ Inert } \\
\text { Fraction }\end{array}$ \\
\hline Otte & $1.33 \pm 0.00^{\mathrm{b}}$ & $0.33 \pm 0.00^{\mathrm{d}}$ & $0.67 \pm 0.00^{\mathrm{a}}$ & $0.67 \pm 0.00^{\mathrm{ab}}$ & $0.67 \pm 0.00^{\mathrm{bc}}$ \\
Budo Egba & $1.67 \pm 0.00^{\mathrm{a}}$ & $1.00 \pm 0.00^{\mathrm{b}}$ & $0.60 \pm 0.00^{\mathrm{ab}}$ & $0.56 \pm 0.19^{\mathrm{bc}}$ & $0.40 \pm 0.19^{\mathrm{cd}}$ \\
Budo Abio & $0.22 \pm 0.19^{\mathrm{de}}$ & $0.33 \pm 0.00^{\mathrm{d}}$ & $0.00 \pm 0.00^{\mathrm{e}}$ & $0.22 \pm 0.19^{\mathrm{de}}$ & $0.22 \pm 0.00^{\mathrm{e}}$ \\
Mubo & $0.33 \pm 0.00^{\mathrm{d}}$ & $1.00 \pm 0.00^{\mathrm{b}}$ & $0.56 \pm 0.51^{\mathrm{b}}$ & $0.89 \pm 0.39^{\mathrm{a}}$ & $1.11 \pm 0.39^{\mathrm{a}}$ \\
Oyun & $0.33 \pm 0.00^{\mathrm{d}}$ & $0.67 \pm 0.00^{\mathrm{c}}$ & $0.22 \pm 0.35^{\mathrm{cd}}$ & $0.44 \pm 0.38^{\mathrm{c}}$ & $0.33 \pm 0.58^{\mathrm{d}}$ \\
Oja gboro & $0.67 \pm 0.00^{\mathrm{c}}$ & $0.67 \pm 0.00^{\mathrm{c}}$ & $0.33 \pm 0.00^{\mathrm{c}}$ & $0.33 \pm 0.57^{\mathrm{d}}$ & $0.67 \pm 0.58^{\mathrm{bc}}$ \\
Olaolu & $0.67 \pm 0.00^{\mathrm{c}}$ & $0.67 \pm 0.00^{\mathrm{c}}$ & $0.22 \pm 0.19^{\mathrm{cd}}$ & $0.67 \pm 0.58^{\mathrm{ab}}$ & $1.00 \pm 0.58^{\mathrm{b}}$ \\
Eroomo & $0.33 \pm 0.00^{\mathrm{d}}$ & $0.00 \pm 0.00^{\mathrm{e}}$ & $0.11 \pm 0.19^{\mathrm{d}}$ & $0.44 \pm 0.19^{\mathrm{c}}$ & $0.56 \pm 0.19^{\mathrm{c}}$ \\
Okeodo & $0.67 \pm 0.00^{\mathrm{c}}$ & $1.33 \pm 0.00^{\mathrm{a}}$ & $0.22 \pm 0.35^{\mathrm{cd}}$ & $0.22 \pm 0.39^{\mathrm{de}}$ & $0.44 \pm 0.39^{\mathrm{cd}}$ \\
Coca cola & $0.67 \pm 0.58^{\mathrm{c}}$ & $0.57 \pm 0.51^{\mathrm{cd}}$ & $0.33 \pm 0.00^{\mathrm{c}}$ & $0.56 \pm 0.19^{\mathrm{bc}}$ & $0.44 \pm 0.39^{\mathrm{cd}}$ \\
Isale Aluko & $0.33 \pm 0.00^{\mathrm{d}}$ & $0.22 \pm 0.19^{\mathrm{d}}$ & $0.44 \pm 0.77^{\mathrm{bc}}$ & $0.56 \pm 0.39^{\mathrm{bc}}$ & $0.38 \pm 0.58^{\mathrm{d}}$ \\
Odoore & $0.19 \pm 0.11^{\mathrm{de}}$ & $0.00 \pm 0.00^{\mathrm{e}}$ & $0.00 \pm 0.00^{\mathrm{e}}$ & $0.67 \pm 0.58^{\mathrm{ab}}$ & $0.22 \pm 0.39^{\mathrm{e}}$ \\
Botanical & $0.00 \pm 0.00^{\mathrm{e}}$ & $0.00 \pm 0.00^{\mathrm{e}}$ & $0.00 \pm 0.00^{\mathrm{e}}$ & $0.00 \pm 0.00^{\mathrm{f}}$ & $0.11 \pm 0.19^{\mathrm{f}}$ \\
garden(CS) & & & & & \\
\hline
\end{tabular}

Mean value with same alphabet along the same column are statistically the same at $\mathrm{p} \leq 0.05$ using Duncan Multiple Range Test, CS: Control Site, BT: Bound To. Values represent mean \pm SD.

Table 5: Fractionation of Cd $(\mathrm{mg} / \mathrm{kg})$ in the Vegetable Farm Soils at some Sites in Ilorin, Nigeria during Rainy Season

\begin{tabular}{llllll}
\hline Site & $\begin{array}{l}\text { Exchangeable } \\
\text { Cd }\end{array}$ & $\begin{array}{l}\text { BT Carbon } \\
\text { fraction }\end{array}$ & $\begin{array}{l}\text { BT Oxides } \\
\text { Fraction }\end{array}$ & $\begin{array}{l}\text { BT Organics } \\
\text { Fraction }\end{array}$ & $\begin{array}{l}\text { Residual/Inert } \\
\text { Cd fraction }\end{array}$ \\
\hline Otte & $0.25 \pm 0.00^{\mathrm{a}}$ & $1.17 \pm 0.10^{\mathrm{a}}$ & $1.08 \pm 0.12^{\mathrm{a}}$ & $0.58 \pm 0.14^{\mathrm{a}}$ & $0.22 \pm 0.09^{\mathrm{b}}$ \\
Budo Egba & $0.25 \pm 0.00^{\mathrm{a}}$ & $1.17 \pm 0.14^{\mathrm{a}}$ & $0.68 \pm 0.12^{\mathrm{b}}$ & $0.33 \pm 0.04^{\mathrm{b}}$ & $0.27 \pm 0.09^{\mathrm{a}}$ \\
Budo Abio & $0.00 \pm 0.00^{\mathrm{c}}$ & $0.33 \pm 0.12^{\mathrm{c}}$ & $0.08 \pm 0.14^{\mathrm{e}}$ & $0.17 \pm 0.13^{\mathrm{d}}$ & $0.22 \pm 0.09^{\mathrm{b}}$ \\
Mubo & $0.00 \pm 0.00^{\mathrm{c}}$ & $0.17 \pm 0.14^{\mathrm{a}}$ & $0.25 \pm 0.00^{\mathrm{c}}$ & $0.33 \pm 0.14^{\mathrm{b}}$ & $0.17 \pm 0.17^{\mathrm{c}}$ \\
Oyun & $0.00 \pm 0.00^{\mathrm{c}}$ & $0.08 \pm 0.14^{\mathrm{d}}$ & $0.17 \pm 0.14^{\mathrm{d}}$ & $0.25 \pm 0.00^{\mathrm{c}}$ & $0.11 \pm 0.10^{\mathrm{f}}$ \\
Ojagboro & $0.25 \pm 0.00^{\mathrm{a}}$ & $0.08 \pm 0.12^{\mathrm{d}}$ & $0.17 \pm 0.14^{\mathrm{d}}$ & $0.17 \pm 0.28^{\mathrm{d}}$ & $0.00 \pm 0.00^{\mathrm{d}}$ \\
Olaolu & $0.08 \pm 0.14^{\mathrm{b}}$ & $0.08 \pm 0.14^{\mathrm{d}}$ & $0.17 \pm 0.29^{\mathrm{d}}$ & $0.08 \pm 0.14^{\mathrm{e}}$ & $0.06 \pm 0.10^{\mathrm{e}}$ \\
Eroomo & $0.00 \pm 0.00^{\mathrm{c}}$ & $0.08 \pm 0.14^{\mathrm{d}}$ & $0.17 \pm 0.14^{\mathrm{d}}$ & $0.17 \pm 0.10^{\mathrm{d}}$ & $0.06 \pm 0.10^{\mathrm{e}}$ \\
Okeodo & $0.00 \pm 0.00^{\mathrm{c}}$ & $0.08 \pm 0.14^{\mathrm{d}}$ & $0.17 \pm 0.14^{\mathrm{d}}$ & $0.08 \pm 0.14^{\mathrm{e}}$ & $0.06 \pm 0.10^{\mathrm{e}}$ \\
Cocacola & $0.25 \pm 0.00^{\mathrm{a}}$ & $0.08 \pm 0.14^{\mathrm{d}}$ & $0.08 \pm 0.14^{\mathrm{e}}$ & $0.08 \pm 0.14^{\mathrm{e}}$ & $0.11 \pm 0.10^{\mathrm{c}}$ \\
Isale Aluko & $0.25 \pm 0.00^{\mathrm{a}}$ & $0.08 \pm 0.14^{\mathrm{d}}$ & $0.17 \pm 0.14^{\mathrm{d}}$ & $0.17 \pm 0.14^{\mathrm{d}}$ & $0.06 \pm 0.10^{\mathrm{e}}$ \\
Odoore & $0.00 \pm 0.00^{\mathrm{c}}$ & $0.08 \pm 0.14^{\mathrm{b}}$ & $0.08 \pm 0.14^{\mathrm{e}}$ & $0.08 \pm 0.14^{\mathrm{e}}$ & $0.05 \pm 0.10^{\mathrm{e}}$ \\
Botanical Garden $(\mathrm{CS})$ & $0.00 \pm 0.00^{\mathrm{c}}$ & $0.00 \pm 0.00^{\mathrm{e}}$ & $0.00 \pm 0.00^{\mathrm{e}}$ & $0.00 \pm 0.00^{\mathrm{f}}$ & $0.00 \pm 0.00^{\mathrm{f}}$ \\
\hline
\end{tabular}

Mean value with same alphabet along the same column are statistically the same at $\mathrm{p} \leq 0.05$ using Duncan Multiple Range Test, CS: Control Site, BT: Bound To. Values represent mean \pm SD. 
Table 6: Fractionation of $\mathrm{Pb}(\mathrm{mg} / \mathrm{kg})$ in the Vegetable Farm Soils at some Sites in Ilorin, Nigeria during Dry Season

\begin{tabular}{lccccc}
\hline Sites & $\begin{array}{l}\text { Exchangeable } \\
\text { Fraction }\end{array}$ & $\begin{array}{l}\text { BT Carbon } \\
\text { Fraction }\end{array}$ & $\begin{array}{l}\text { BT Oxides } \\
\text { Fraction }\end{array}$ & $\begin{array}{l}\text { BT Organics } \\
\text { Fraction }\end{array}$ & $\begin{array}{l}\text { Residuals/ Inert } \\
\text { Fraction }\end{array}$ \\
\hline Otte & $0.67 \pm 0.14^{\mathrm{a}}$ & $2.85 . \pm 0.00^{\mathrm{c}}$ & $2.33 \pm 0.00^{\mathrm{d}}$ & $1.31 . \pm 0.00^{\mathrm{b}}$ & $3.33 \pm 0.00^{\mathrm{c}}$ \\
Budo Egba & $0.33 \pm 0.11^{\mathrm{c}}$ & $2.73 \pm 0.00^{\mathrm{d}}$ & $2.10 \pm 0.09^{\mathrm{de}}$ & $1.30 \pm 0.00^{\mathrm{def}}$ & $4.00 \pm 0.00^{\mathrm{b}}$ \\
Budo Abio & $0.00 \pm 0.00^{\mathrm{e}}$ & $0.83 \pm 0.00^{\mathrm{g}}$ & $0.33 \pm 0.10^{\mathrm{g}}$ & $1.46 \pm 0.00^{\mathrm{b}}$ & $0.41 \pm 0.00^{\mathrm{gh}}$ \\
Mubo & $0.17 \pm 0.00^{\mathrm{d}}$ & $3.00 \pm 0.00^{\mathrm{b}}$ & $0.43 \pm 0.00^{\mathrm{fg}}$ & $4.00 \pm 0.00^{\mathrm{b}}$ & $1.67 \pm 0.00^{\mathrm{d}}$ \\
Oyun & $0.33 \pm 0.07^{\mathrm{c}}$ & $3.33 \pm 0.09^{\mathrm{b}}$ & $0.67 \pm 0.39^{\mathrm{ef}}$ & $4.00 \pm 0.00^{\mathrm{b}}$ & $1.00 \pm 0.00^{\mathrm{e}}$ \\
Ojagboro & $0.00 \pm 0.00^{\mathrm{e}}$ & $3.00 \pm 0.11^{\mathrm{b}}$ & $5.25 \pm 0.25^{\mathrm{ab}}$ & $3.00 \pm 0.10^{\mathrm{c}}$ & $5.00 \pm 0.00^{\mathrm{a}}$ \\
Olaolu & $0.67 \pm 0.11^{\mathrm{a}}$ & $5.00 \pm 0.00^{\mathrm{a}}$ & $4.33 \pm 0.00^{\mathrm{b}}$ & $1.33 \pm 0.00^{\mathrm{def}}$ & $3.00 \pm 0.00^{\mathrm{c}}$ \\
Eroomo & $0.00 \pm 0.00^{\mathrm{e}}$ & $1.33 \pm 0.00^{\mathrm{e}}$ & $0.41 \pm 0.19^{\mathrm{fg}}$ & $1.67 \pm 0.00^{\mathrm{d}}$ & $4.15 \pm 0.00^{\mathrm{b}}$ \\
Okeodo & $0.67 \pm 0.11^{\mathrm{a}}$ & $2.70 \pm 0.00^{\mathrm{a}}$ & $3.77 \pm 0.29^{\mathrm{c}}$ & $2.25 \pm 0.25^{\mathrm{cd}}$ & $0.50 \pm 0.00^{\mathrm{fg}}$ \\
Coca cola & $0.33 \pm 0.00^{\mathrm{c}}$ & $2.33 \pm 0.00^{\mathrm{d}}$ & $1.03 \pm 0.09^{\mathrm{e}}$ & $4.20 \pm 0.58^{\mathrm{b}}$ & $0.67 \pm 0.00^{\mathrm{f}}$ \\
IsaleAluko & $0.58 \pm 0.14^{\mathrm{b}}$ & $0.67 \pm 0.11^{\mathrm{f}}$ & $5.33 \pm 0.21^{\mathrm{a}}$ & $7.33 \pm 0.39^{\mathrm{a}}$ & $1.10 \pm 0.00^{\mathrm{e}}$ \\
Odoore & $0.00 \pm 0.00^{\mathrm{e}}$ & $0.00 \pm 0.00^{\mathrm{g}}$ & $0.17 \pm 0.19^{\mathrm{gh}}$ & $1.00 \pm 0.29^{\mathrm{ef}}$ & $0.57 \pm 0.00^{\mathrm{fg}}$ \\
Botanical & $0.00 \pm 0.00^{\mathrm{e}}$ & $0.00 \pm 0.00^{\mathrm{g}}$ & $0.00 \pm 0.00^{\mathrm{h}}$ & $0.33 \pm 0.17^{\mathrm{f}}$ & $0.30 \pm 0.00^{\mathrm{h}}$ \\
Garden(CS) & & & & & \\
\hline
\end{tabular}

Mean value with same alphabet along the same column are statistically the same at $\mathrm{p} \leq 0.05$ using Duncan Multiple Range Test, CS: Control Site, BT: Bound To. Values represent mean \pm SD.

Table 7: Fractionation of $\mathrm{Pb}(\mathrm{mg} / \mathrm{kg})$ in the Vegetable Farm Soils at some Sites in Ilorin, Nigeria during Rainy Season

\begin{tabular}{llllll}
\hline Site & $\begin{array}{l}\text { Exchangeable } \\
\text { Fraction }\end{array}$ & $\begin{array}{l}\text { BT Carbon } \\
\text { Fraction }\end{array}$ & $\begin{array}{l}\text { BT Oxides } \\
\text { Fraction }\end{array}$ & $\begin{array}{l}\text { BT Organics } \\
\text { Fraction }\end{array}$ & $\begin{array}{l}\text { Residual/Inert } \\
\text { Fraction }\end{array}$ \\
\hline Otte & $8.00 \pm 0.00^{\mathrm{e}}$ & $8.50 \pm 0.25^{\mathrm{c}}$ & $7.25 \pm 0.25^{\mathrm{c}}$ & $4.25 \pm 0.25^{\mathrm{cd}}$ & $0.79 \pm 0.26^{\mathrm{cd}}$ \\
Budo Egba & $7.08 \pm 0.12^{\mathrm{f}}$ & $7.14 \pm 0.13^{\mathrm{de}}$ & $6.00 \pm 0.10^{\mathrm{de}}$ & $2.83 \pm 0.38^{\mathrm{de}}$ & $0.39 \pm 0.10^{\mathrm{ef}}$ \\
Budo Abio & $4.08 \pm 0.12^{\mathrm{g}}$ & $0.83 \pm 0.12^{\mathrm{g}}$ & $3.50 \pm 0.26^{\mathrm{g}}$ & $1.42 \pm 0.08^{\mathrm{g}}$ & $0.28 \pm 0.09^{\mathrm{f}}$ \\
Mubo & $1.25 \pm 0.25^{\mathrm{h}}$ & $0.50 \pm 0.25^{\mathrm{h}}$ & $1.92 \pm 0.13^{\mathrm{h}}$ & $0.75 \pm 0.25^{\mathrm{hi}}$ & $0.84 \pm 0.89^{\mathrm{c}}$ \\
Oyun & $9.00 \pm 0.25^{\mathrm{d}}$ & $8.30 \pm 0.42^{\mathrm{cd}}$ & $8.92 \pm 0.63^{\mathrm{b}}$ & $1.00 \pm 0.25^{\mathrm{h}}$ & $0.40 \pm 0.20^{\mathrm{ef}}$ \\
Ojagboro & $9.92 \pm 0.52^{\mathrm{c}}$ & $4.33 \pm 0.12^{\mathrm{ef}}$ & $6.08 \pm 0.12^{\mathrm{de}}$ & $4.67 \pm 0.13^{\mathrm{c}}$ & $0.33 \pm 0.00^{\mathrm{efg}}$ \\
Olaolu & $10.83 \pm 0.63^{\mathrm{b}}$ & $18.33 \pm 0.72^{\mathrm{a}}$ & $7.33 \pm 0.14^{\mathrm{bc}}$ & $5.25 \pm 0.50^{\mathrm{b}}$ & $1.57 \pm 0.63^{\mathrm{a}}$ \\
Eroomo & $6.58 \pm 0.12^{\mathrm{fg}}$ & $7.67 \pm 0.13^{\mathrm{d}}$ & $4.33 \pm 0.13^{\mathrm{fg}}$ & $2.33 \pm 0.12^{\mathrm{efg}}$ & $0.64 \pm 0.19^{\mathrm{d}}$ \\
Okeodo & $8.58 \pm 0.12^{\mathrm{de}}$ & $8.25 \pm 0.00^{\mathrm{cd}}$ & $4.58 \pm 0.12^{\mathrm{f}}$ & $2.50 \pm 0.00^{\mathrm{ef}}$ & $0.45 \pm 0.16^{\mathrm{e}}$ \\
Cocacola & $11.33 \pm 0.29^{\mathrm{a}}$ & $9.58 \pm 0.12^{\mathrm{b}}$ & $5.50 \pm 0.25^{\mathrm{e}}$ & $2.42 \pm 0.14^{\mathrm{ef}}$ & $0.35 \pm 0.10^{\mathrm{efg}}$ \\
Isale Aluko & $8.00 \pm 0.25^{\mathrm{e}}$ & $9.42 \pm 0.13^{\mathrm{bc}}$ & $9.67 \pm 0.13^{\mathrm{a}}$ & $5.58 \pm 0.14^{\mathrm{a}}$ & $0.91 \pm 0.10^{\mathrm{b}}$ \\
Odoore & $6.50 \pm 0.25^{\mathrm{fg}}$ & $4.67 \pm 0.13^{\mathrm{e}}$ & $6.50 \pm 0.00^{\mathrm{d}}$ & $3.08 \pm 0.02^{\mathrm{d}}$ & $0.58 \pm 0.26^{\mathrm{de}}$ \\
Botanical Garden & $0.92 \pm 0.08 \mathrm{i}$ & $2.17 \pm 0.13^{\mathrm{f}}$ & $1.83 \pm 0.38^{\mathrm{hi}}$ & $1.33 \pm 0.14^{\mathrm{gh}}$ & $0.22 \pm 0.09^{\mathrm{fg}}$ \\
(CS) & & & & & \\
\hline
\end{tabular}

Mean value with same alphabet along the same column are statistically the same at $\mathrm{p} \leq 0.05$ using Duncan Multiple Range Test, CS: Control Site, BT: Bound To. Values represent mean \pm SD.

\section{CONCLUSION}

The study is an important risk assessment tool, remediation guide and a measure of heavy metal availability in the soils of vegetable farms in Ilorin, Nigeria. It is indicated in the results that most soils in Ilorin, Kwara State used for growing vegetables need remediation or the use should be discontinued for growing vegetables. The study further enunciates that soils for agricultural purposes should be well protected to prevent contamination by heavy metals.

It is hereby recommended that soils for growing vegetables should be continuously monitored to ensure that concentration of readily available forms or fractions of cadmium (Cd) and lead $(\mathrm{Pb})$ are maintained below the permissible limit to avoid phytoabsorption. 


\section{REFERENCES}

Association of Official Analytical Chemists. (2000). Official Methods of Analysis of Association of official Analytical. chemists International, 17th ed., AOAC, Washington D.C, USA.

Atayese, M.O., Eigbadon, A.J., Oluwa, K.A. and Adesodun, J.K. (2009). Heavy metal contamination of Amaranthus grown along major highways in Lagos. Nigerian African Crop Science Journal, 16 (4):225-235

Ashraf, M. A., Maah, M. J., Yusoff, I., Wajid, A. and Mahmood, K. (2012) "Sand mining effects, causes and concerns: a case study from Bestari Jaya, Selangor, Peninsular Malaysia," Scientific Research and Essays, 6(3): 1216-1231.

Cabral, A.R. and Lefebvre, G. (1998). "Use of sequential extraction in the study of heavy metal retention by silty soils." Water, Air, and Soil Pollution, 102 (3-4): 329-344

Davidson, C.M., Urquhart, G.J., Ajmone-Marsan, F., Biasioli, M., Costa Duarte. A. and DiazBarrientos, E. (2006). Fractionation of potentially toxic elements in urban soils from five European cities by means of a harmonized sequential extraction procedure. Analytica. Chimica. Acta, 565:63-72.

Debnárová, A. and Doleța, H. (2010). Assessment of Heavy Metal Pollution (Cd, Cu, Pb, $\mathrm{Hg}$ ) in Urban Soils of Roadsides in Borno. Transactions on Transport Sciences, 3: 113-154

Deng, H., Gu, T.1., Li, M.1. and Deng. X. (2012). Comprehensive assessment model on heavy metal pollution in soil. International Journal of Electrochemical Science, 7: 5286 5296.

Diaz-de Alba, M., Galindo-Riano, M. D., Casanueva- Marenco, M. J. and GarciaVargas, M. (2011). Assessment of the metal pollution, potential toxicity and speciation of sediments from Algeciras Bay (South Spain) using chemo metric tools. Journal of hazardous materials, 190 (13):177-87.

Förstner, U. (1993). Metal speciation-general concepts and applications. International Journal of Environmental Analytical Chemistry, 51(1-4):5-23.

Gupta, S., Lakshmi, A.J., Majunath, M.N. and
Prakash, J. (2005). Analysis of nutrient and antinutrient content of underutilized green leafy vegetables. Food Science and Technology, 38: 339-345

Haung, J., Haung, R., Jiao, J. J. and Chen, K. (2005). "Speciation and mobility of heavy metals in mud, in coastal reclamation areas in Chenzhen, China." Environmental Geology, 53(1):221-228.

Herawati, N., Suzuki, S., Hayashi, K., Rivai, I. F. and Koyama, H. (2010). Cadmium, copper accumulation in different rice cultivars and genotypes. Field crops Research, 83: 271-281.

Iwegbue, C. M. A., Bassey, F. I., Tesi, G. O., Nwajei, G. E. and Tsafe, A. I. (2013). Assessment of heavy metal contamination in soil around cassava processing mills in sub - urban areas of Delta state, southern Nigeria. Nigerian Journal of Basic and Applied Sciences, 21(2): 96-104.

Joksic, A. S., Katz, S.A., Horvat, M. and Milacic, R. (2005). Comparison of single and sequential extraction procedures for assessing metal leaching from dredged coastal sediments. Water, Air, Soil, Pollution, 162: 265-283.

Kabata-Pendias, A., Pendias, F. M., Howari, B. and Banat, K. M. (2004). "Assessment of Fe, $\mathrm{Zn}, \mathrm{Cd}, \mathrm{Hg}$, and $\mathrm{Pb}$ in the Jordan and Yarmouk River sediments in relation to their physicochemical properties and sequential extraction characterization," Water, Air, and Soil Pollution, 132 (1-2): 43-59

Levy, D. B., Barbarick, K. A., Siemer, E. G. and Sommers, L. E. (1992) "Distribution and partitioning of trace metals in contaminated soils near Leadville, Colorado," Journal of Environmental Quality, 21 (2):185-195.

Lokeshwari, H. and Chandrappa, G.T. (2006). Impact of heavy metal contamination of Bellandur Lake on soil and cultivated vegetation. Curriculum Science, 91(5): 622627.

Menzies, N.W, Donn, M. J. and Kopittke, P. M. (2007). Evaluation of extractants for estimation the phytoavailable trace metals in soils. Environmental Pollution, 
145(1):121-130.

Manceau, A., Marcus, M.A. and Tamura, N. (2002). Quantitative speciation of heavy metals in soils and sediments by synchrotron $\mathrm{x}$-ray techniques. p. 579. In P.A. Fenterel et al. (ed.) Applications of synchrotron radiation in low-temperature geochemistry and environmental science. Vol. 49. Mineral Society of America, Washington DC

Maiz, M., Esnaola, V. and Millán, E. (2000), Evaluation of heavy metal availability in contaminated soils by a short sequential extraction procedure. Journal of Science of TotalEnvironment, 206:107-115.

Obrador, A., Alvarez, J. M., Lopez-Valdivia, L. M., Gonzalez, D., Novillo, J. and Rico, M. I. (2007). Relationships of soil properties with $\mathrm{Mn}$ and $\mathrm{Zn}$ distribution in acidic soils and their uptake by a barley crop, Geoderma, 137 (3-4): 432-443.

Oluwatosin, G.A., Adeoyolanu, O.D., Ojo, A.O., Are, K.S., Dauda, T.O. and AduramigbaModupe, V.O. (2010). Heavy metal uptake and accumulation by edible leafy vegetable (Amaranthus bybridus L.) grown on urban valley bottom soils in southwestern Nigeria. Soil and Sediment Contamination, 19: $1-20$

Rayment, G. E. and Higginson, F.R. (1992). Australian Laboratory Handbook of Soil and Water. Inkata Press Pty Ltd, Melbourne. 330pp.

Reddy, K.R., Hettiarachci H., Gangathulasi, J., Bogner, J. E. and Lagier, T. (2002). Geotechnical properties of synthetic municipal solid waste. International Journal of Geotechnology and Engineering, 3: 429-438

Rhoades, J. D. (1982). Cation exchange capacity. In: Page AL, Miller RH, Keeney DR, editors. Methods of Soil Analysis, Part 2. 2nd edition. Vol. 9. Madison, Wis, USA:
Agronomy Society of America and Soil Science Society of America. pp. 149-157.

Song, B., Lei, M., Chen, T., Zheng, Y., Xie, Y., Li, X. and Gao, D. (2008). Assessing the health risk of heavy metals in vegetables to the general population in Beijing, China. Journal of Environmental Sciences, 21: 1702-1709

Tessier, A. P., Campbell, G. C. and Blsson, M. (1979). "Sequential extraction procedure for the speciation of particulate trace metals." Analytical Chemistry, 52(1): 45-53.

World Health Organization (2006). World Health Report. World Health Organization; Geneva, Switzerland

Xian, X. (1989). Effect of chemical forms of cadmium, zinc and lead in polluted soils on their uptake by cabbage plants. Plant Soil, 113:257-264

Yadawe, T. A. (2011). Analysis of physicochemical and heavy metals concentration in soil of Bija. Environmental Monitoring and Assessment, 130:271-279.

Ying, C., Pingping, W., Yufang, S. and Yibin, Y. (2013). Health risk assessment of heavy metals in vegetables grown around battery production area. University/School of Biosystems Engineering and Food Science, Hangzhou - PR China. 71(.2):126-132.

Zerbe, J., Sobczyński, T., Elbanowska, H. and Siepak, J. (1999). "Speciation of heavy metals in bottom sediments of lakes," Polish Journal of Environmental Studies, 8 (5): 331-339.

Zurera, G, Moreno, R, Salmeron, J. and Pozo, R. (1989). Heavy metal uptake from greenhouse border soils for edible vegetables. Journal of Science and Food Agriculture, 49:307-314. 